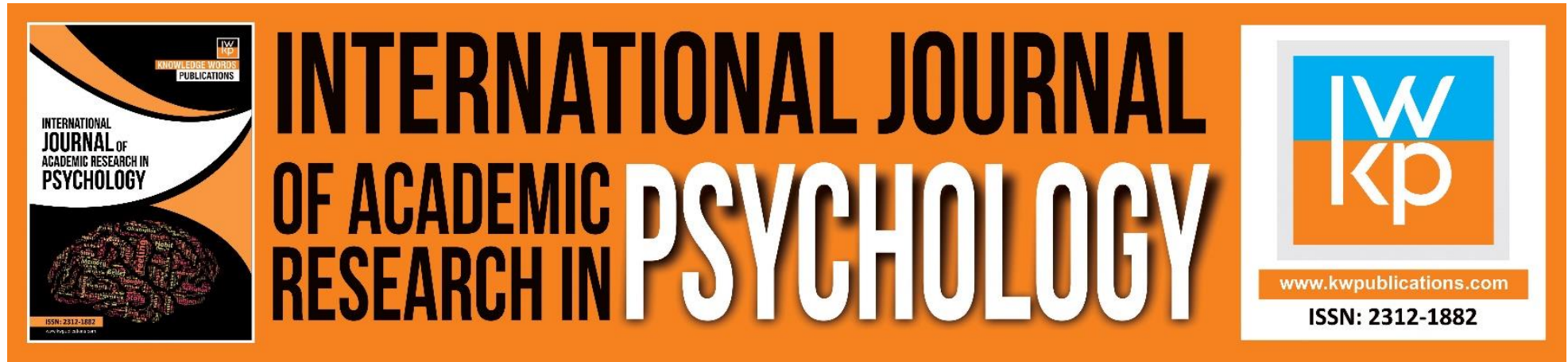

\title{
Role of Leadership Styles and Self Efficacy on Employees' Job Involvement in Enugu State
}

Obinna Osita Ike, Ifeanyichukwu Chukwudi Eze, Moses Ichongo Ukeh

To Link this Article: http://dx.doi.org/10.46886/IJARP/v3-i1/2102

DOI:10.46886/IJARP/v3-i1/2102

Received: 19 January 2016, Revised: 21 February 2016, Accepted: 10 March 2016

Published Online: 29 March 2016

In-Text Citation: (Ike et al., 2016).

To Cite this Article: Ike, O. O., Eze, I. C., \& Ukeh, M. I. (2016). Role of Leadership Styles and Self Efficacy on Employees' Job Involvement in Enugu State. International Journal of Academic Research in Psychology. 3(1), 1-10.

Copyright: (C) 2016 The Author(s)

Published by Knowledge Words Publications (www.kwpublications.com)

This article is published under the Creative Commons Attribution (CC BY 4.0) license. Anyone may reproduce, distribute, translate and create derivative works of this article (for both commercial and non-commercial purposes), subject to full attribution to the original publication and authors. The full terms of this license may be seen at: http://creativecommons.org/licences/by/4.0/legalcode

Vol. 3, No. 1, 2016, Pg. 1 - 10

https://kwpublications.com/journals/journaldetail/IJARP

JOURNAL HOMEPAGE

Full Terms \& Conditions of access and use can be found at https://kwpublications.com/pages/detail/publication-ethics 


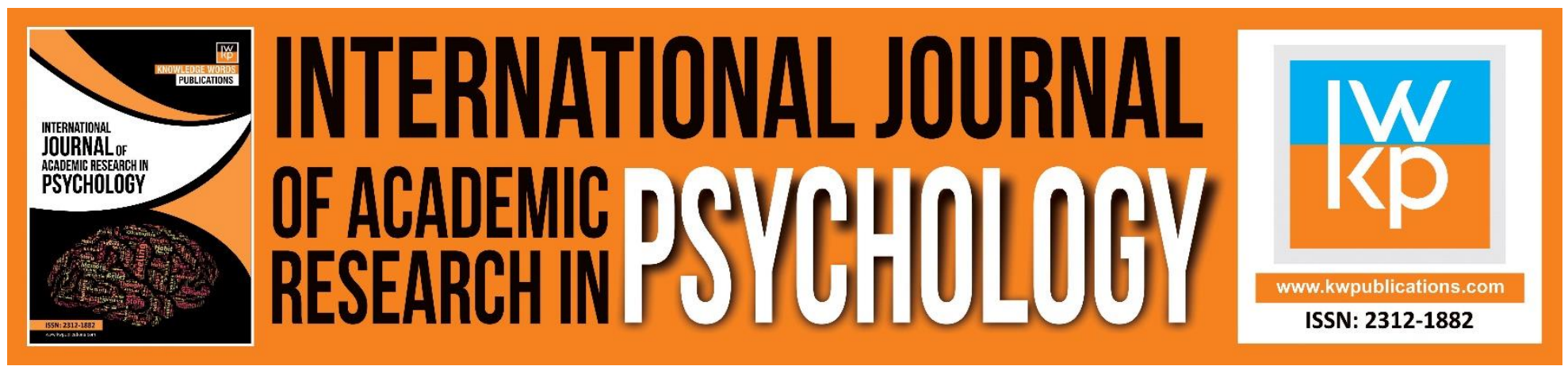

\title{
Role of Leadership Styles and Self Efficacy on Employees' Job Involvement in Enugu State
}

\section{Obinna Osita Ike ${ }^{\mathrm{a}}$, Ifeanyichukwu Chukwudi Eze ${ }^{\mathrm{b}}$, Moses Ichongo Ukeh ${ }^{b}$}

aDepartment Of Psychology, Enugu State University of Science and Technology, Enugu State, Nigeria, bepartment Of Psychology, Nigerian Police Academy, Wudil, Kano State, Nigeria.

Email: obinnaike44@yahoo.com

\begin{abstract}
The study investigated the role of leadership styles and self efficacy on employees' job involvement. Two hundred and eighty participants took part in the study. Three instruments were used for data collection. They were Leadership Behavior Description Questionnaire (LBDQ), Self-efficacy Scale (SES) and Job Involvement Scale (JIS). Two hypotheses were tested. Two-way analysis of variance (ANOVA) was used to analyze the data. Result shows that there is a significant difference between different types of leadership styles on job involvement as well as self efficacy and job involvement. The results were discussed in terms of their relevance in work setting and suggestions for further research made. Keywords: Leadership Style, Self Efficacy, Job Involvement, Category of Employees.
\end{abstract}

\section{Introduction}

Research on work behavior have taken a step forward by recognizing the role of leadership style and self efficacy in the job involvement of employees in an industrial setting (Compeau \& Higgins 2001; Schwarzer, 1997; Schyns 2001). This is because no meaningful economic development could take place in any organization without first improving the productivity index which is a derivative of proper job involvement (Osoba, 1983).

Job involvement is a necessary condition if the employee is to accept fully the organizational demands placed upon him/her by his/her membership in the organization. It represents a cognitive or belief state of psychological identification with ones present job (Kanungo, 1982). The process of job involvement in work has been the concern of the psychologists as they have tended to focus on organizational conditions that lead to job involvement such as meaningfulness of work, adequacy of supervision etc. Hence, it is viewed as behaviour rather than merely an internal process which implies that when workers are committed to a course, a person or activity, they express this by an overt act. A relationship process without an overt behavioural component cannot be considered as involvement (Winner \& Gechman, 1977). This goes a long way in portraying that behaviour which are considered important for achieving performance in workers encompasses a total work behaviour 
of the individuals in relation to the job such as committing his total energy to the job, minimizing waste and helping co-workers (Saleh, 1981). This stresses the internalization of values about the goodness of work, or the importance of work in the worth of the person and perhaps it thus, measures the ease with which the person can be further socialized by an organization. However, this internalization implies the degree to which a person identifies psychologically with his work (that is the extent to which the total work situation is an important part of life) and effect of work on the individual self concept (i.e. the extent to which perceived job success affect self esteem). Thus, job involvement can be considered as an important measure of organizational effectiveness that may be at least in part influenced by leadership style and self efficacy (Kristsonis, 2004).

In conceptualizing the level of job involvement of workers in Nigerian industries today, one needs to consider proper leadership style and self efficacy as factors that play a great role in the level of workers job involvement. Thus, in the world of human being, one principal factor which makes societies move forward, develop or improve their living condition is leadership. Leaders' behavior affects employees' satisfaction and involvement towards organizational goals and objectives (Xirasagar, 2008). Leadership is an influence process where the ease or difficulty of exerting influence is a function of the favourableness of the group, task, situation and the leader (Yahchouchi, 2009). Although it has been recognized that the favourableness of the leadership style to be adopted is dependent on different variables such as task structure, group and the leader member relations as well as power position (Ofordu, 2005). One of the basic problems of organization is how to reconcile, coordinate or integrate member needs or goals with organizational requirements and objectives. Hence, the imperativeness of a good leadership style is inevitable in a dynamic and complex organizational climate where motivational problem of relating man and system is a major concern (Shamir et al., 2002). However, the most perplexing problems controlling managers and supervisors have been to determine the leadership style most conducive to promoting effective work group. Empirically studies directed towards finding that style which is most effective have yielded inconclusive and often contradictory results (Bartolo \& Furlonger, 2002; Katerberg \& Home, 1981; Walder, 1995).

There have been many leadership styles put forward and researchers have approached the problem of clarifying these leadership style from different dimensions (Bass \& Avolio 1990; Macallister, 2004). Flamholtz $(1986,1990)$ indentified six leadership styles which falls under three categories as in the table below:- 
INTERNATIONAL JOURNAL OF ACADEMIC RESEARCH IN PSYCHOLOGY

Vol. 3, No. 1, 2016, E-ISSN: 2312-1882 @ 2016 KWP

Table 1: The Leadership Styles and Categories

\begin{tabular}{|l|l|l|}
\hline Category & Style & Definition \\
\hline Directive & Autocratic & $\begin{array}{l}\text { Declares what is to be done without } \\
\text { explanation. }\end{array}$ \\
\cline { 2 - 3 } & $\begin{array}{l}\text { Benevolent } \\
\text { Autocratic }\end{array}$ & $\begin{array}{l}\text { Declares what is to be done with an } \\
\text { explanation. }\end{array}$ \\
\hline Interactive & Consultative & $\begin{array}{l}\text { Gets opinions before deciding on the plan } \\
\text { presented. }\end{array}$ \\
\cline { 2 - 3 } & Participative & $\begin{array}{l}\text { Formulates alternatives with group, then } \\
\text { decides. }\end{array}$ \\
\hline Nondirective & Consensus & $\begin{array}{l}\text { All in group have equal voice in making } \\
\text { decisions. }\end{array}$ \\
\cline { 2 - 3 } & Laissez-Faire & Leaves it up to group to decide what to do. \\
\hline
\end{tabular}

However, in the course of this study, the leadership styles that the researchers have focused on are categorized under two dimensions, namely task oriented or initiating leadership style and considerate or employees centered leadership style (Lawrence, 2007).

Few studies have confirmed the importance of leadership styles and self efficacy on job involvement of workers (Compeau \& Higgins, 2001; Kohn, 1994; Schyns, 2001). Self efficacy influences the job involvement of workers (Schyns, 2001). It relates to a person's perception of their ability to reach a goal. It is the belief that one has the capabilities to execute the course of action required to manage prospective situation (Bandura, 1997). Most researchers have confirmed a positive correlation between self-efficacy and job involvement (Kohn, 1994; Schyns, 2001). A study conducted by Compeau and Higgins (2001) was done to determine the role of individuals' belief about their abilities to competently use computers in the determination of computer use. The researcher found out that an individual's level of involvement in the computer task depends to a great extent on the level of the individual's self-efficacy.

Shamir et al, (1993) proposed that leadership style enhances self-efficacy of employees. . However, self-efficacy and leadership style act as a catalysts in propelling people to be involved or not in a work and that job involvement could be seen as a moderating variable between leadership style and self efficacy and it is only on 'involved employees' does a positive relationship between satisfaction and performance becomes evident (Williams, 1996).

Previous studies suggested that leadership styles and self-efficacy influence employees' job involvement (Fu et al., 2006; Schyn, 2001). Based on the above researchs and findings, these hypotheses were formulated;

$\mathrm{H}_{1}$ : There will be no statistically significant difference in job involvement between employees experiencing initiating structure leadership style and those experiencing considerate leadership styles.

$\mathrm{H}_{2}$ : There will be no statistically significant difference in job involvement between employees with high self-efficacy and those with low self-efficacy.

Therefore, the authors aim to find out the role of leadership styles and self-efficacy on employees' job involvement. The findings will add to existing literature and guide captains of industries/policy makers on the dynamics of work attitude and its implications for a holistic organizational functioning. 
INTERNATIONAL JOURNAL OF ACADEMIC RESEARCH IN PSYCHOLOGY

Vol. 3, No. 1, 2016, E-ISSN: 2312-1882 @ 2016 KWP

\section{Method}

\section{Design}

The design of the study is $2 \times 2$ factorial design based on the structure of the study.

\section{Participants}

The participants comprised of the entire staff strength of Wilson Nigeria Limited, Nsukka, Enugu State totaling three hundred and thirteen (313) employees of Wilson Nigeria Limited Nsukka. The participants consisted of one hundred and forty-nine (149) males and one hundred and thirty-one (131) females. The participants' age ranged from twenty (20) to fifty (50) years with mean age of thirty eight (38) years.

\section{Instruments}

The research involves three instruments, leadership style scale, self-efficacy scale and job involvement scale. The instruments were put into one questionnaire that has four sections. Section A contains questions on demographic information like gender, age, marital status, years of service, educational qualification.

Section B, contains questions about leadership style. The scale was developed by Fleishman (1953) and it consists of 48 items. The response format range from strongly agree (5 points) to strongly disagree (1 point). Fleishman (1953) reported reliability co-efficient of the scale to be. 92 for consideration and .68 for initiating structure items. In order to adopt it for Nigeria context, Ofordu (2005) validated the scale using 35 items with a Crombach alpha of .89 for consideration and .75 for initiating structure items. From the instrument on leadership scale administered, the highest score was one hundred and seventy five (175) and the lowest thirty five (35). To categorise considerating and initiating structure leadership styles is from the average score of participants on the leadership questionnaire, 83 and above were considered as considerating leadership style while 82 and below were considered as initiating structure leadership style. Average score represents the total responses on items on LBDQ divided by the total number of participant. Therefore, one hundred and thirty six (136), participants scored 83 and above and were considered as considerating leadership style while one hundred and forty four (144) scored 82 and below and were considered as having initiating leadership style.

Section C contains on questions on self-efficacy. The scale was developed by Schwarzer and Jerusalem (1993) and it consists of 10 items with reliability co-efficient of .75. The possible responses to the scale range from not at all "true" to exactly "true". The coding also ranged from 1 to 4 respectively. In order to adopt this scale for Nigeria context, the instrument was subjected to validity and reliability tests by the author with a reliability coefficient of .74 and a validity index of .57. From the average score of participants on self-efficacy scale, 29 and above were considered as high selfefficacy while 28 and below were considered as low self-efficacy.

Section D contains questions on job involvement. The scale was developed by Lodahl and Kejner (1965), reporting a split half reliability .57 for nurses, .67 for engineers and .80 for students. Ejiogu (1986) adopted and validated the scale with a split half reliability of .76. It consists of 20 -items, the response format range from "strongly agree" to "strongly disagree". The coding also ranged from 1 to 5 respectively. 


\section{Procedure}

The researchers introduced themselves to the manager of the company and intimated him of the research they were conducting. They informed him about the confidentiality of the employees responses to the questionnaire and he gave his approval. The administrative manager was directed to guide the researchers in meeting the employees through their sectional heads from where the questionnaires were administered. The researchers conducted the study in Wilson Nigeria Limited, Nsukka, Enugu state. There was no sampling technique used since the researchers made use of the whole staff of the company totaling three hundred and thirteen (313). The employees completed the questionnaires on leadership style, self-efficacy and job involvement. All data were collected at one point through there sectional heads.

From the three hundred and thirteen (313) copies of questionnaire distributed to the entire three hundred and thirteen staff of Wilson Nigeria Limited Nsukka, twenty (20) copies were wrongly filled while another thirteen (13) copies were returned blank. Thirty three (33) copies of the questionnaire which were wrongly filled and the blank ones were discarded and were left with two hundred and eighty (280) copies of the participants' questionnaire for statistical analysis of the data.

\section{Method of Data Analysis}

Two-way ANOVA was employed for statistical analysis because the two independent variables operated under two levels.

\section{Results}

Table 2: Mean scores and Standard deviations of the various groups of leadership styles (considerate or initiative) and staff efficiency (high or low) on job involvement.

\begin{tabular}{|l|l|l|l|l|}
\hline Variable & Level & Mean scores & $\begin{array}{l}\text { Standard } \\
\text { deviation }\end{array}$ & Number \\
\hline Leadership & Considerate & 58.62 & 11.95 & 136 \\
Style & Initiative & 54.58 & 13.31 & 144 \\
\hline Self & High & 58.55 & 12.63 & 143 \\
Efficacy & Low & 54.44 & 12.70 & 137 \\
\hline
\end{tabular}

Table 2 shows that there is a significant difference in the mean scores and standard deviation of the different levels of leadership styles and self efficacy on job involvement.

Table 3: Summary table of two-way ANOVA for the role of leadership styles and self efficacy on the job involvement of the employees.

\begin{tabular}{|l|l|l|l|l|l|}
\hline Source & $\begin{array}{l}\text { Sum of } \\
\text { squares }\end{array}$ & df & $\begin{array}{l}\text { Mean } \\
\text { square }\end{array}$ & F & Significance \\
\hline Leadership style (A) & 899.409 & 1 & 899.409 & 5.77 & $*$ \\
\hline Self- efficacy (B) & 1031.873 & 1 & 1031.893 & 6.62 & $*$ \\
\hline A X B & 587.723 & 1 & 587.723 & 3.77 & NS \\
\hline ERROR & 43037.382 & 76 & 155.933 & & \\
\hline & & & & & \\
TOTAL & 940932.00 & 280 & & & \\
\hline CORRECTED & 45745.486 & 279 & & & \\
\hline
\end{tabular}


Significant difference was found between leadership styles on employees' job involvement ( $F=5.77$ : $\mathrm{P}<$.05). Employees with considerate leadership style reported more involvement in their job than those employees with initiating structure. Their means as shown in table two were (mean $=58.62 ;$ SD =11.95), while Mean =54.58); SD $=13.31$ was for employees with initiating leadership style. This suggests that employees with considerate leadership style are more involved in their job. Also, a significant difference was found on self-efficacy and employees job involvement $(F=6.62 ; P<.05)$. This shows that employees with high self efficacy (mean $=58.55 ; \mathrm{SD}=12.63$ ) are more involved in their job more than those with low self-efficacy ( $m e a n=54.44 ; S D=12.67$ ). This shows that leadership style and self-efficacy are undeniably imperative in job involvement.

\section{Discussion}

In this study, there is a significant difference between the two categories of leadership styles (considerate and initiative) on employees' job involvement. The results are consistent with Rukmani etal., (2010) finding which shows that employee(s) who were given more autonomy (freedom to operate i.e., considerate) were more likely to have higher job involvement than those not given autonomy to operate (initiative). The finding further agreed with Fielder's (1976) contingency model of leadership which proposed that effective leader is a joint function of leader characteristics and situational characteristics and those effective leaders are those who see their followers as similar to themselves. In addition, considerating leadership styles have strong and superior influence on employee job involvement (Krause, 2004). The result equally agreed with Likert (1967) finding where he hypothesized that leaders who obtain the highest productivity are supportive, friendly and helpful rather than hostile and tries to treat people in a sensitive and considerate way. Other studies which showed that considerate leadership style significantly influence job involvement of employees includes (Ofordu, 2005; Bass \& Avolio, 1990 \& 1995; Koztonshi \& Doherty, 1986; Rukmani et.al 2010). Furthermore, there is a significant difference in job involvement between employees with high selfefficacy and those with low self-efficacy (Compeau \& Higgins, 2001). The finding agreed with Bandura (1987) concept of self-determinism which shows that employees with high self-efficacy were associated with high job involvement and the zeal to accomplish, which breeds strong sense of competence that helps cognitive processes in commitment towards one's work. He further stated that employees with low self-efficacy have pessimistic thoughts about their accomplishment and personal development and are bound to be less involved in their job. The finding is in consonance with the study by Sims (1997) where he found out that people who have high self-efficacy in their domain of operation adapt better socially, makes friends easier and are more willing to work with others as well as committing themselves to their work while those with low efficacy have difficulty making friends and working with others as well not showing much commitment to their work.

However, this study has some limitations. The study restricted only on initiative (task) and considerate (employee centered) leadership styles. Further studies can investigate other types of leadership style. The participants were only workers of Wilson Nigeria Limited Nsukka, Enugu State. A wider population would have added more credence to the external validity of the findings. Thus, further research with a wider population is recommended. 


\section{Conclusion}

In organizational framework, the above findings call for the need for proper leadership style and a high self-efficacy to be put in place since they are catalyst that binds other factors together. Thus, a cordial industrial harmony exists only when there is compatibility between the employees need and organizational goals, which is only exemplified through good leadership structure and a high selfefficacy. This will undeniably enhance workers commitment towards their work which in return helps in actualizing the organizational stated goals and objectives. Human existence is justified when all the input to enhance, co-ordinate and better life is observed in people's performance in their various areas of endeavor. This is made possible in work setting through good leadership style and selfefficacy since it is evident that it can significantly influence job involvement of employees (Ofordu, 2005; Compeau \& Hyggins, 2001; Bass \& Avolio, 1990; 1995; Watson, 1994; Bandura, 1987; Mehmet et.al, 2014; Rukmani et al., 2010). Therefore leadership style and self-efficacy as a hall mark of any organization is no longer perceived as performance which connotes efficient utilization of industrial resources by a worker or group of workers. Rather they are factors which uplift the total outcome of goal performance as it contributes to the realization of desired organizational objectives. However, the imperativeness of leadership style and self-efficacy on employees' job involvement in work setting cannot be overlooked or ignored since its understanding is essential for a healthy work behavior.

\section{References}

Bandura, A. (1987). Self-regulation of Motivation and Action Through Goal Systems. In V. Hamilton \& N.H. Fryda (Eds); cognition, motivation and affect: A cognitive Science View. Dirdecht: Martinus Nijholl.

Bandura, A. (1997). Self-efficacy: The Exercise- of Control. New York: Freeman.

Bartolo, K., \& Furlonger, B. (2000). Leadership and job satisfaction among aviation fire fighters in Austria. Journal of managerial psychology, 15:87-97.

Bass, B. M., \& Avolio, B. (1990). Transformational Leadership development: Manual for the Multifactor Leadership Questionnaire, Palo Alto, CA Consulting Psychologist Press.

Bass, B. M., \& Avolio, B. (1995). MLQ Multifactor leadership Questionaire, Technical Report. Redwood City, CA Mind garden.

Callister, T. (2004). Leadership style and perceived benefits of electronic data interchange for the retail industry. Department of textiles and consumer sciences. Florida State University.

Compeau, D., \& Higgins, C. (2001). Computer Self-Efficacy. Development of a Measure and Initial test._http://www.misq.or/archivist/voll9/issue2/voll9n2art4.htm.

Ejiogu, K. C. (1986). Reward Preference, Marital Status and Sex as Predictors of job Involvement. Unpublished M.sc Thesis University of Nigeria, Nsukka.

Fiedler, F. E. (1976). A Theory of Leadership Effectiveness. New York: McGraw-Hill.

Fleishman, E. A. (1953). The Description of Supervisory Behaviour, Journal of Personnel Psychology, 37, 1-6.

Fu, P., Tsui, A., Liu, J., Song, J., Jiang, Y., Jia, L., Li, Y. J., Hui, C., \& Wu, W. (2006). CEO personal values and middle manager responses: The mediating role of leadership behavior and organizational culture. Granted by council of the Hongkong special administrative region, China. 
INTERNATIONAL JOURNAL OF ACADEMIC RESEARCH IN PSYCHOLOGY

Vol. 3, No. 1, 2016, E-ISSN: 2312-1882 @ 2016 KWP

Kanungo, R. N. (1982). Measurement of job and work Involvement. Journal of Applied Psychology, 67,341-349.

Kohn, A. (1994). The Truth About self-esteem. Phi Delta kappa, 76,272-283.

Koztowshi, S. W., \& Doherty, M. L. (1989). Integration of climate and leadership. Examination of a neglected issue. Journal of Applied Psychology, 74, 546-553.

Katerberg, R., \& Horne, P. W. (1981). Effects of within group and between groups variation in leadership. Journal of applied psychology, 66: 28 -223. Doi:10.103710021 9010.66.2.218.

Kritonis, A. (2004). Leadership in organization: National Implications. International journal of scholarly academic intellectual diversity, 8, 11-8

Lawrence, P. G. (2007). Neohumility/humility and business leadership: do they belong together? Economics and management, University of Minnesota, Morris.

Likert, R. (1967). The Human Organization: its management and Value. New York: McGraw-Hills.

Lodahl, T. M., \& Kejner, M. (1965). The Definition and Measurement of Job Involvement. Journal of Applied Psychology, 49, 24-33.

Mehmet, F. Y., Abdurrahim, E., \& Pauline, E. (2014). Analysis of Organizational Justice, Supervisor Support and Organizational Commitment: A Case Study of Energy Sector in Nigeria. Journal of business studies quarterly, Vol 5 (3).

Ofordu, I. R. (2005). The Role of Supervision and Gender on Employee Job Involvement. Unpublished M.sc Thesis. Psychology Department, University of Nigeria, Nsukka.

Osoba, R. G. (1983). Factors Related to productivity (A preliminary Report) American Psychology Association.

Rukmaani, K., Ramesh, M., and Yayacrishnan, J. (2010) Effects of Leadership Styles on Organizational Effectiveness. European Journal of Social Sciences, Volume 15 (3).

Saleh, S. (1981). A Structural View of Job Involvement and The Differentiation from Satisfaction and Motivation. International review of applied psychology, 30, 17-29.

Schwarzer, R., \& Jerusalem, M. (1993). General perceived self-efficacy in 14 cultures. http://www.yorku.ca/faculty/academic/schwarze/World 14. htm.

Schwarzer, R. (1997).The assessment of Optimistic self-beliefs. Comparison of the German, Spanish $\&$ Chinese versions of the general self-efficacy Scale. Applied Psychology: An International Review 46 (1) 69-88.

Shamir, B., Zakay, E., Breinin, E., \& Popper, M. (2002), leadership and social identification in military units. Journal of Applied social psychology, 30,612-640.

Schyns, B. (2001). "Self - Monitoring and Occupational self-efficacy of Employees and their relation to perceived Transformational Leadership". Current Research in Social Psychology, 7:30-42.

Sims, P. (1997). Awakening Brilliance: How to inspire children to become successful learner. Marietta, GA: Bay Hampton publications.

William, H. (1996). The Essence of Managing Groups and Teams. London: Prentice Hall.

Winner, Y., \& Gechman , S. (1977). Commitment. A Behavioural Approach to job Involvement. Journal of Vocational Behaviour, 10,47-52.

Xirasagar, S. (2008). Transformational, transactional and laissez - faire leadership among physician executives. Journal of health organization and management. Vol. 222 (6) PPI599613. 


\section{INTERNATIONAL JOURNAL OF ACADEMIC RESEARCH IN PSYCHOLOGY}

Vol. 3, No. 1, 2016, E-ISSN: 2312-1882 @ 2016 KWP

Yahchonchi, G. (2009). Employees perceptions of Lebanese mangers leadership styles and

organizational commitments. International journal of leadership studies. Vol 4, pp. 127-140 